\title{
Climate change and settlement level impacts
}

Deanne Bird ${ }^{1}$, Robert McLeman ${ }^{2}$, Guðrún Gísladóttir ${ }^{3}$, Ilan Kelman ${ }^{4}$, Marius Warg Næss ${ }^{5}$, Guðrún Pétursdóttir ${ }^{6}$, Guðrún Jóhannesdóttir ${ }^{7}$

1 Risk Frontiers, Department of Environmental Sciences, Macquarie University, Sydney

2 Department of Geography and Environmental Studies, Wilfrid Laurier University, Waterloo, Canada

3 Institute of Life and Environmental Sciences, Institute of Earth Sciences, and the Nordic Volcanological Center, University of Iceland, Askja Sturlugata 7, 101 Reykjavík, Iceland 4 Institute for Risk and Disaster Reduction and Institute for Global Health, University College London, U.K. and University of Agder, Kristiansand, Norway

5 Norwegian Institute for Cultural Heritage Research (NIKU), Tromsø, Norway

6 Institute for Sustainability Studies, University of Iceland

7 Department of Civil Protection and Emergency Management, National Commissioner of the Icelandic Police. Skógarhlíð 14, 105 Reykjavík, Iceland

\section{Introduction}

It is widely suggested that poorer nations, typically located in the lower latitudes, will bear the brunt of climate change impacts (e.g. Mendelsohn et al., 2006). However, adverse impacts are expected to occur both sooner and more intensely in high latitudes than in other locations (ACIA, 2005; AMAP, 2011; IPCC, 2013). Particular concerns for tundra and Arctic coastal regions include rising surface temperatures that cause near-surface (upper 3.5m) melting of permafrost, more frequent rainfall events that raise flood risks, potentially higher rates of coastal erosion, and changes to the spatial extent, thickness, and seasonality of sea ice (EngenSkaugen et al., 2008; Flannigan et al., 1998; Hanssen-Bauer, 2009; IPCC, 2012, 2013). Below the treeline, warming temperatures are expected to stimulate widespread pest outbreaks in boreal forests and to trigger further ecosystem changes in plant and animal species distributions, some of which may be non-linear in nature (Sambaraju et al., 2012; Scheffer et al., 2012; Stralberg et al., 2015). While some of these changes may be beneficial to northern communities and settlements (e.g. more rain may reduce the occurrence of forest fires), most impacts will present significant challenges to their adaptive capacity. 
To illustrate just some of the various ways in which climate change will challenge the adaptability of northern communities, this chapter examines the impacts and adaptation strategies of changing climate in three case study locations in the mid-to-high latitudes of the northern hemisphere. The first case study looks at a small Icelandic community that has evolved in an environment exposed to extreme weather and catastrophic natural hazard events. It considers how climate change is expected to exacerbate these already difficult conditions, and discusses land use planning and structural mitigation strategies that are being implemented to help the community adapt. The second case study looks at the sparsely populated region of Canada's Eastern Ontario Highlands and how the changing climate affects residents' livelihoods and wellbeing. It recognises that while warming temperatures may produce potential benefits, such as drawing more tourists and retirees to the area, the cumulative effects of physical changes in the region threaten the overall adaptive capacity of the year-round population. The third case study looks at how livelihood opportunities are being created because of climate change in northern Norway. It argues that because of the related temporary and permanent migration into the north, the traditional indigenous migratory patterns of the Saami people are likely to suffer. The final section of this chapter discusses these issues in relation to the wider literature on climate change adaptation.

\section{Case study 1: Natural hazards and climate change impacts in Vík, southern Iceland}

The municipality of Mýrdalshreppur of 489 residents (Statistics Iceland, 2013), including the coastal village Vík in Mýrdal with 293 residents (Statistics Iceland, 2014a), is the southernmost municipality in Iceland, covering $755 \mathrm{~km}^{2}$ (Fig. 1). Surrounded by glaciers, volcanoes and black sandy beaches, the south coast region attracted over a million overnight stays from local and international tourists from 2012 to 2013, the highest recorded outside of the capital city region (Statistics Iceland, 2014b). Yet, the processes forming the landscape that visitors find so attractive pose challenges and threats to the settlement and its industries, continually shaping the lives of the residents. This case study examines the development of Vík in a very dynamic landscape and discusses the mitigation measures and evacuation strategies that are in place for the village and its inhabitants. 


\section{Regional and historic setting}

The Mýrdalshreppur municipality is limited by the North Atlantic Ocean in the south and rugged mountains and hills in the north, which includes the Mýrdalsjökull glacier and Katla volcano (Fig. 1). The Eyjafjallajökull volcano is a close neighbour to the west. The glacial river Jökulsá on Sólheimasandur marks the western boundary and to the east the municipality stretches out to the Mýrdalssandur outwash plain. Many rivers within the municipality drain Mýrdalsjökull, limiting transport to and from the area, until they were bridged during the $20^{\text {th }}$ century.

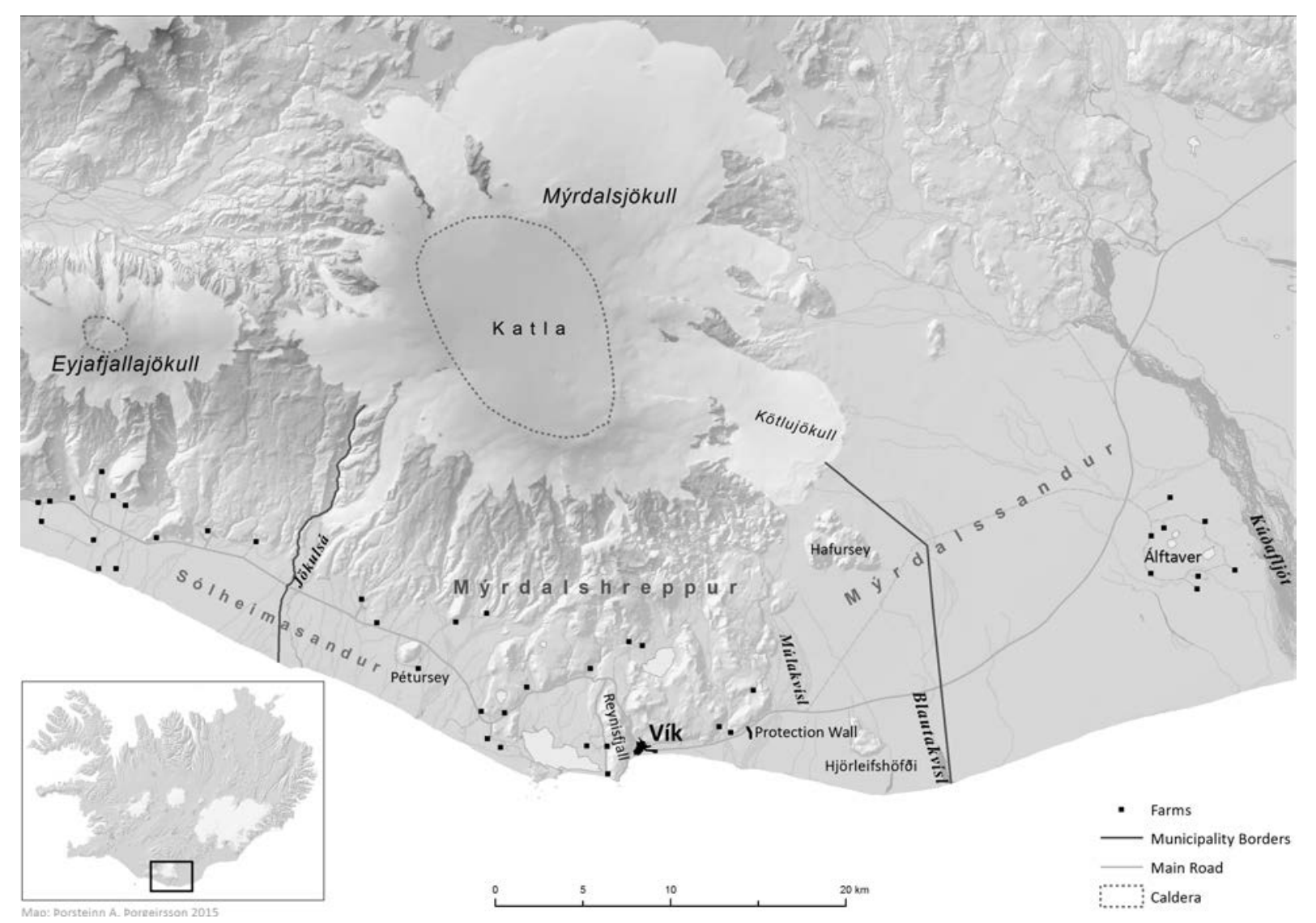

Figure 1: The Mýrdalshreppur municipality and its surroundings. Map by Porsteinn Ari Porgeirsson.

From the beginning of its development, Vík has been restricted geographically. The hills above the coast were used for farming and the village grew on the very small sandy coast ( $\sim 200 \mathrm{~m}$ in width) below (Fig. 2). Net erosion and coastal depletion, processes driven by ocean currents and very strong waves, continually rework the very dynamic coast. Coastal 
expansion also occurs when sediment is transported with easterly currents and trapped along Vík's coast.

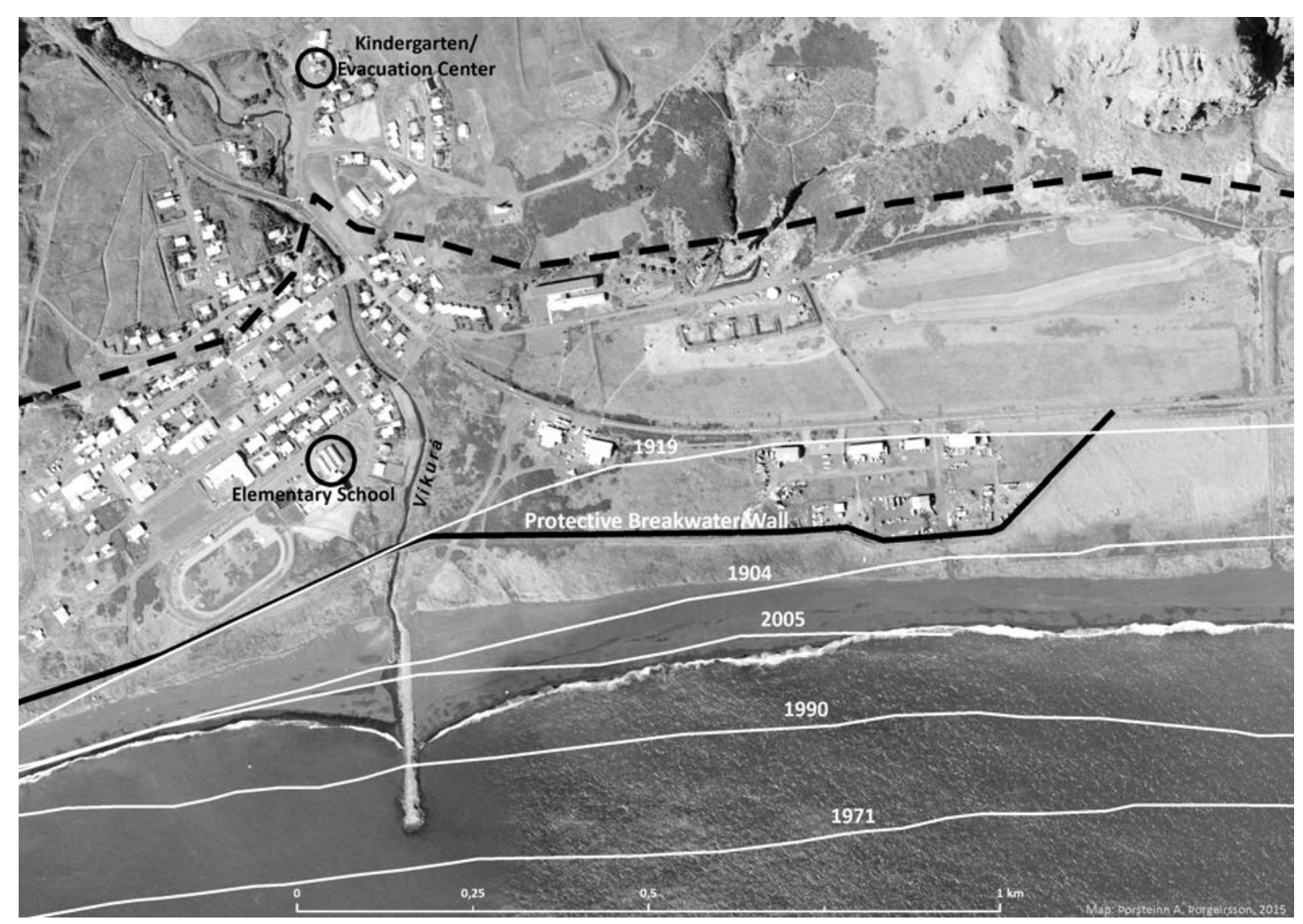

Figure 2: The village Vík in Mýrdalur. The location of the coastline at different times is marked (Vegagerðin, 2008). The area south of the black-hatched line shows the evacuation zone. The settlement on the hills is north of the hatched line, and the developed area on the sandur $^{1}$ area is south of the hatched line and west of the brook, Víkurá. Aerial photograph by Loftmyndir ehf. Map by Porsteinn Ari Porgeirsson.

The climate is mild with an annual average temperature of $6.29^{\circ} \mathrm{C}$ and precipitation of $2517.6 \mathrm{~mm}^{2}$ (Veðurstofa Íslands, 2014), ensuring the region is viable for farming.

Consequently, residents of Mýrdalshreppur have traditionally been farmers and prior to the development of the village, two farms were located on the hill above Vík's coastline. The development of Vík as a trade centre in 1887 resulted in more diversified occupations, and various services and manufacturing emerged to serve the farming community and growing

\footnotetext{
1 An outwash plain formed through the deposition of sediment transported by glacial meltwater.

${ }^{2}$ During the 10-year period from 2001 to 2010.
} 
urban settlement (Ólafsson, 1987, 1993). During this time, goods were transported on open boats to Vík, despite the lack of a harbour along the entire municipality's $\sim 40 \mathrm{~km}$ sandy coast. Offshore fishing was also practiced among farmers and early settlers. Prior to Vík's development, residents accessed goods from the nearest trade centres at Stokkseyri and Eyrarbakki some $120 \mathrm{~km}$ away, crossing a number of glacier rivers that were not bridged at the time (Sverrisson, 1988). In recent decades, tourism has become an increasingly important part of the local economy (personal communication, Ásgeir Magnússon, 14 November 2014). This includes both national and international tourism-Vík is within a day-return trip from hotels in Reykjavík and has become a popular summerhouse destination for residents living in the capital.

The village reached its peak population of 382 in 1966, with residents pursuing a diverse range of livelihoods (Haraldsson, 1982). Since then, the population has been decreasing, particularly people under the age of 50 (Table 1). As younger generations have been leaving Vík, the population has been aging, with a growing proportion of people over 50 years of age, especially women. One of the reasons for the decline in youth could relate to the relatively limited number of livelihood options in Vik, that lead many of the younger people to seek employment elsewhere.

Table 1: Vík’s population in 1991 and 2014 (from Statistics Iceland, 2014a).

\begin{tabular}{lcccc} 
& \multicolumn{2}{c}{1991} & \multicolumn{2}{c}{2014} \\
& Male & Female & Male & Female \\
\hline 30 years and under & 88 & 76 & 67 & 60 \\
31 to 50 years & 41 & 37 & 26 & 24 \\
51 to 70 years & 28 & 28 & 33 & 40 \\
Over 70 years & 16 & 18 & 22 & 21 \\
Sub-total & 173 & 159 & 148 & 145 \\
TOTAL & \multicolumn{2}{c}{332} & \multicolumn{2}{c}{293} \\
\hline
\end{tabular}

To combat the issue of depopulation, the Icelandic parliament approved the Strategic Regional Plan for 2014-2017 to 'create greater equality of opportunity in work and services for all people in the country, to mitigate differences in living standards, and to promote the sustainable development of the regions in all parts of the country' (Parliament of Iceland, 
2014; p.1). Through the Strategic Regional Plan, there will be a focus on 'halting' depopulation in small settlement centres and rural areas. While it is not entirely clear how this will be achieved, there is strong support within the plan to enhance higher education and training among populations living in vulnerable communities in addition to diversifying livelihood opportunities by supporting a variety of business enterprises. Progress on the successes of this plan is due to be announced in 2015 .

Furthermore, the Icelandic Government implemented the Iceland 2020 policy statement, which aims to build an efficient, dynamic and diversified economy and society (Prime Minister's Office, 2011). The Iceland 2020 policy statement provides recommendations, including the aim to reduce the unemployment rate by $4 \%$ between 2010 and 2020, i.e. from $7 \%$ to $3 \%$, in all towns and communities across the country. Improvements have been noted with the annual average unemployment rate dropping to 5\% in 2014 (Statistics Iceland, 2015). This figure, however, varied considerably spatially and seasonally. A contributing factor to this decrease is the significant increase in international tourism since 2012 (Icelandic Tourist Board, 2015), which has not only increased employment opportunities but also improved the national economy. At present tourism accounts for more foreign exchange income than any other industry in Iceland, and employment among people working in tourism-related work has increased much more than in any other businesses (Óladóttir, 2015).

\section{Natural hazards, climate change and adaptation strategies}

The residents of Vík have inherited local knowledge of Katla eruptions (Bird, 2010; Bird et al., 2011; Jóhannesdóttir, 2005; Jóhannesdóttir \& Gísladóttir, 2010), and have direct experience of the 2010 Eyjafjallajökull eruption (Bird \& Gísladóttir, 2012, 2014) and of ongoing processes of coastal erosion (Mýrdalshreppur, 2010). These geo-tectonic risks are of considerable concern to residents, and have been explicitly incorporated into the regional plan for Vík (Mýrdalshreppur, 2013b). By contrast, Vík residents do not view climate change as a direct threat to their community (Jónsdóttir, 2012), even though it is expected that coastal erosion will be exacerbated by climate change induced sea level rise (Veðurstofa Íslands, 2013). Furthermore, the warming climate has led to the widespread retreat of Iceland's glaciers (Björnsson \& Pálsson, 2008), and research has shown that the resultant decrease in lithospheric pressure leads to an increase in volcanism due to the increased production of magma and/or vigorous crustal deformation caused by isostatic rebound (e.g. Compton et al., 2015; Maclennan et al., 2002; Pagli \& Sigmundsson, 2008; Sigvaldason et al., 1992). 


\section{Coastal erosion}

The most obvious threat that impacts people's everyday life in Vík is coastal erosion (Mýrdalshreppur, 2013b, a), for a large part of the settlement is situated on a beach less than $400 \mathrm{~m}$ from the coastline (Fig. 2). The narrow beach in the early $20^{\text {th }}$ century benefitted from the sediment deposited south of Hjörleifshöfði (situated east of Vík (Fig. 1)) during the jökulhlaup (glacial outburst flood) following the 1918 Katla eruption. This sediment was gradually transported by ocean currents and deposited at Vík, causing the beach to expand steadily until 1971, when it reached its maximum extent (Fig. 1). Since then, erosional processes have been gradually reducing the size of the beach, and by 2005 the western part of the coastline was similar to what it had been a hundred years earlier (Ísaksson et al., 2005). In the absence of further sediment deposition up-current, the beach will continue to erode. It is expected that the rate of beach erosion will be exacerbated as climate change induced sea level rise and associated storm surges and coastal erosion affects the south coast of Iceland (Veðurstofa Íslands, 2013). The combined future impacts on the settlement may be reminiscent of those experienced by inhabitants of Vík in the late $19^{\text {th }}$ and early $20^{\text {th }}$ centuries, when houses in the village were recurrently flooded and houses and boats were destroyed (Ólafsson, 1991; Sveinsson, 1988; Sverrisson, 1988).

Given the intensity of coastal erosion since 1971 (Ísaksson et al., 2005), the municipality has considered it to be one of the major threats to the village. In order to reduce the impacts of storm surges on the settlement and to halt the erosion, a protective coastal breakwater wall was built in 1994 (Mýrdalshreppur, 2010). In 2011, a sedimentary trap wall (groin) (Fig. 2) was built perpendicular to the coast to trap sediment west of the wall. Future plans (Mýrdalshreppur, 2010, 2013b) outline the reconstruction and extension of the sedimentary trap wall ( $7.5 \mathrm{~m}$ high extending $300 \mathrm{~m}$ offshore) and a similar one is planned for development to the east of the village in 2016 (Pingskjal 855 - 495. mál, 2014).

\section{Volcanic eruptions}

Katla, sitting to the northeast of Vík and blanketed by the Mýrdalsjökull glacier, is renowned as Iceland's most hazardous volcano. Katla has the potential to melt through the $\sim 400 \mathrm{~m}$ thick glacial ice in 1-2 hours, generating a catastrophic jökulhlaup (glacial outburst flood) with a peak discharge of 100,000-300,000 $\mathrm{m}^{3} \mathrm{~s}^{-1}$ (Björnsson, 2002). Other hazards associated with a Katla eruption are heavy tephra fallout, lightning strikes (Larsen, 2000), and tsunami triggered by jökulhlaup (Guðmundsson et al., 2008). 
The well-documented post-1500 history of Katla indicates eruptions occur twice a century on average, with the last confirmed one having occurred in 1918. Minor eruptions that do not break the glacier surface, and/or shallow magma intrusions are thought to be responsible for a number of small, sudden jökulhlaups down Jökulsá in 1999 and Múlakvísl in 1955 and 2011 (Galeczka et al., 2014; Guðmundsson \& Gylfason, 2005). The more recent flood destroyed the bridge linking the national highway, causing havoc to transport and tourist routes.

Nearly all residents living in the evacuation zone (Fig. 2) are aware of the procedure they should follow if an emergency warning is issued, and have stated they would follow it during a real emergency (Bird et al., 2011). When an eruption does occur, all residents staying and living on the sandy beach in Vík will have 30 minutes to prepare to evacuate to their local evacuation centre on the hill. These areas host almost all tourist accommodation, services, the school, and the industrial area. The kindergarten located on the hill above the beach (Fig. 2) will serve as an evacuation centre (Lögreglustjórinn á Hvolsvelli et al., 2013).

Based on their inherited knowledge, residents of Vík are more concerned about tephra than tsunami. Some residents believe that a Katla eruption would bring positive benefits to the area, in terms of coastal expansion due sand deposition, similar to what happened in 1918 (Bird et al., 2011; Jóhannesdóttir \& Gísladóttir, 2010), while others believe that a Katla eruption might actually increase future tourist visits (Bird et al., 2010; Jóhannesdóttir, 2005).

Although many studies have indicated that a warming climate will lead to an increase in subglacial volcanic activity (e.g. Compton et al., 2015; Maclennan et al., 2002; Pagli \& Sigmundsson, 2008; Sigvaldason et al., 1992), Tuffen (2010) warns that there is currently insufficient research to predict whether or not there will be a statistically significant increase. Moreover, the thinning glaciers will result in a reduction of ice available for meltwater thus potentially reducing volcanically induced jökulhlaup discharge. However, other perils may become more apparent, such as edifice instability, and there is a greater likelihood for more explosive eruptions (Tuffen, 2010), which can produce large quantities of tephra that is dangerous to human health (Rose \& Durant, 2009).

Given the concerns of the residents, and the negative impact tephra had on people's health, livelihoods and everyday living during the 2010 Eyjafjallajökull eruption (Bird \& Gísladóttir, 
2012, 2014; Carlsen et al., 2012a; Carlsen et al., 2012b), long term risk-reduction strategies need to be found. While no specific long-term plans for tephra fallout have been developed for Vík, it is expected that those who are sensitive (e.g. the elderly and those with respiratory problems) will be evacuated from the region if large tephra fallout occurs during a future eruption (personal communication, Ásgeir Magnússon, 14 November 2014).

During past Katla eruptions, jökulhlaup have flooded along the hills from the sandur area towards Vík (Loftsson, 1930). In order to minimize risk, a protection wall was built. However, a recent flood simulation model (Verkfræðistofan Vatnaskil, 2014) indicates that the present protection wall would not prevent flooding towards Vík during an event similar to that as the 1918 eruption. The worst-case scenario shows that a $0.5-2.5 \mathrm{~m}$ flood could impact most businesses in Vík as well as the elementary school and many residential homes (Verkfræðistofan Vatnaskil, 2014). Until new risk-reduction strategies can be implemented, the entire lowland will need to be evacuated to higher ground during a Katla eruption (personal communication, Ásgeir Magnússon, 14 November 2014).

\section{Land use planning}

Vík originally emerged as an unplanned settlement, with the first houses established on the sandur approximately 200m from the ocean (Ólafsson 1948 in Ólafsson, 1991). Residential development began on the hill above the sandur in the early $20^{\text {th }}$ century, especially after the 1918 Katla eruption when settlers realised it was unsafe to build along the coast due to volcanic hazard risk (Haraldsson, 1982). In subsequent decades, however, construction on the sandur continued to develop irregularly. The 1950s brought new residential, industrial, and service developments to the area, and with it came advice from the National Planning Agency and others that no further construction should take place on the sandur (Hannesson, 1950). This advice was not always heeded, even when the official land use planning was implemented in 1970 (Sveinsson, 1988). For example, maps from the 1975-1995 plan (Mýrdalshreppur, 1977) show some residential development on the hill above the sandur area, but most development was actually taking place on the sandur. The new elementary school was built approximately $400 \mathrm{~m}$ from the coastline at that time, which was criticised for its location by local residents (Jóhannesdóttir, 2005; Jóhannesdóttir \& Gísladóttir, 2010). 
The most recent plan, which was accepted in 2013, includes the development of adaptation strategies for coastal erosion for the period 2012-2028 (Mýrdalshreppur, 2013b, a). Building restrictions are now in place for areas close to the coast, and a new residential area is planned on the hills above the beach. Service and industrial areas will be allowed to further develop around their present location given that protection walls will be constructed. The municipality plans to change the location of the main road along the present coastline by drilling a tunnel through the mountain Reynisfjall (Fig. 1), although this plan seems to contradict residents' concerns of the on-going coastal erosion.

\section{Case study 2: Climate adaptation and resilience in the Eastern Ontario}

\section{Highlands ${ }^{3}$}

The Eastern Ontario Highlands (EOH) is a sparsely populated area less than a two-hour drive west of Ottawa (Fig. 3). Despite its proximity to Canada's national capital, the physical, demographic, cultural, economic, and social characteristics of the EOH could not be more different. The EOH cover an area of approximately $3,000 \mathrm{~km}^{2}$ of heavily glaciated upland country, its landscape characterized by extensive forests, thin soils, and many lakes and rivers. The region has important ecological significance being the headwaters for three major river systems, and its biological diversity is such that virtually all species present at time of European contact can be found there today - a rarity in more populated parts of Ontario.

\footnotetext{
${ }^{3}$ This case study is based on empirical work conducted by Dr. McLeman and colleagues between 2007 and 2014. More details can be found in McLeman (2008, 2009, 2010), McLeman \& Gilbert (2008), McLeman et al. (2010) and McLeman \& Ford (2013).
} 


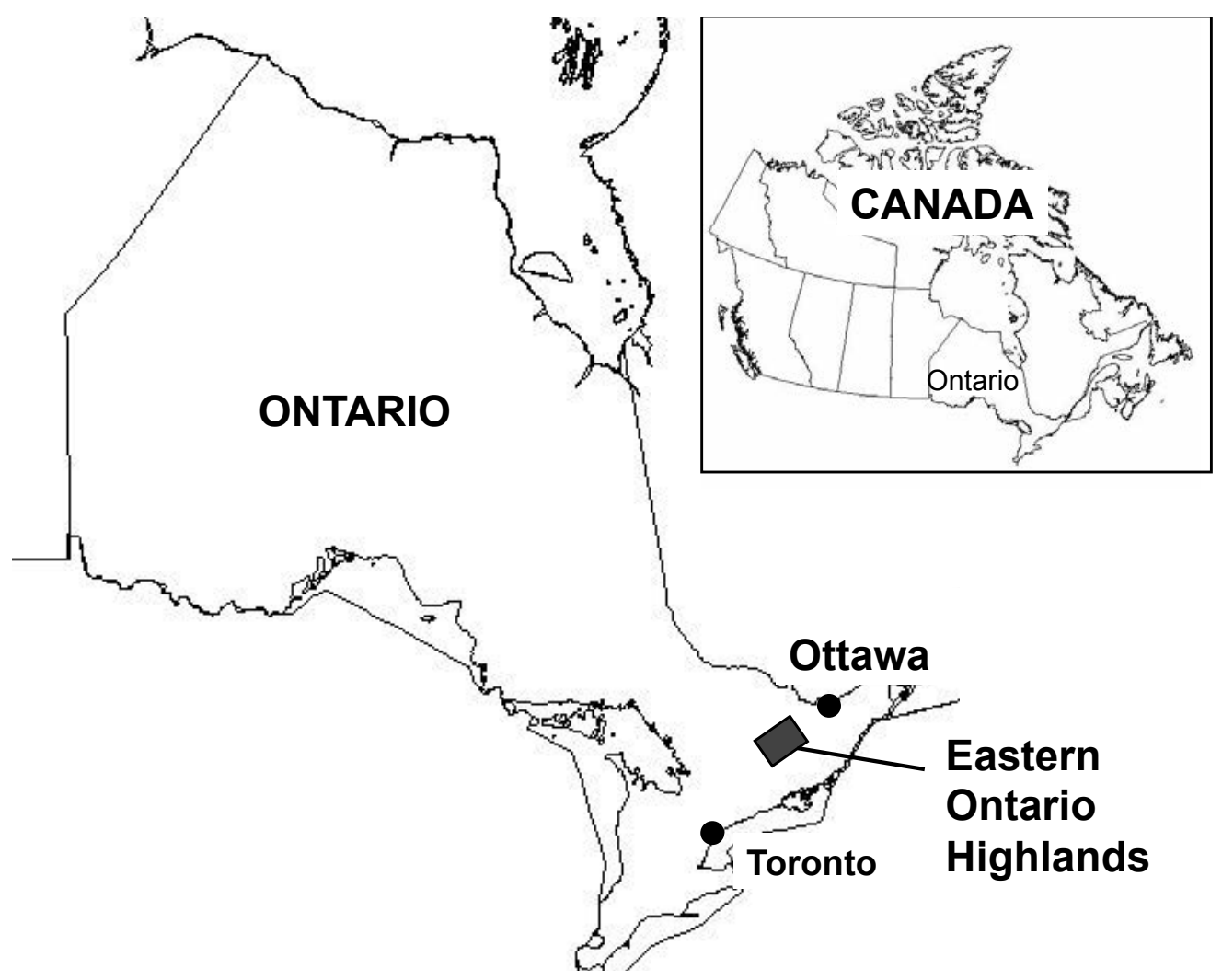

Figure 3: Location of the Eastern Ontario Highlands

Human population densities in the EOH are less than two per $\mathrm{km}^{2}$, with most settlement occurring along a small number of roads ${ }^{4}$. There are no cities in the EOH. The largest named settlement is the village of Northbrook, with a population of less than 1,000 . The average age is over fifty and getting older each year. Population aging is being driven by two concurrent phenomena: a steady out-migration of young people that have reached the age of 18 , and an in-migration of people in their late fifties and sixties from other parts of Ontario who, for cultural reasons, choose to retire to a waterfront home.

The reasons for the outflow of young people are common to many rural and sparsely populated areas. There are few year-round employment opportunities. Private sector employment in the EOH consists disproportionately of low-wage, seasonal employment in service industries, especially tourism-related ones. The region attracts tens of thousands of visitors each year, who come to camp, fish, hunt, and go boating. There is also a summertime influx of temporary residents, referred to as "cottagers", who maintain lakeside recreation properties. Summer visitors generate a ten-week boom surge in employment and trade for

\footnotetext{
${ }^{4}$ All population data taken from: Census of Canada (2011)
} 
locally owned small businesses. Outside the tourist economy, most private sector employment is found in the construction trade, small-scale forestry, and aggregate mining. This employment can also be highly seasonal.

There are no post-secondary educational institutions within easy driving distance of the $\mathrm{EOH}$. Most high school graduates leave the region to study or find permanent employment, and do not return. For those still in school, recreation and amusement consists of traditional outdoor activities like fishing, hunting, snowmobiling, and riding all-terrain vehicles (ATVs).

Childhood activities common in other parts of Ontario - like organized hockey and soccer or piano lessons - are not available to children in the EOH. A common complaint among youth is the lack of high-speed Internet at home and the poor cell phone network across the EOH. Although access to information and communications technology (ICT) has improved in the most populated parts of the EOH over the past decade, the quality and speed of broadband and wireless services lag far behind other parts of Ontario (McLeman et al., 2010). ICT access is particularly important to young people in the $\mathrm{EOH}$, and its poor quality provides a significant incentive for many to leave the region as soon as they can. Poor ICT infrastructure also impedes the ability of local businesses to grow - another reason why young people must leave to find work.

Like outdoor tourists, retirees are attracted to the region precisely because it is underdeveloped in comparison with the rest of Ontario. Waterfront properties are still affordable relative to other parts of Ontario because the EOH are so remote. The lack of industry or economic development means the lakes and rivers are remarkably pollution free, and the summertime air quality is markedly superior to that in Ontario's large cities.

\section{Adaptation to climatic variability in the $\mathrm{EOH}$}

Residents of the EOH have historically been highly adaptable to climatic uncertainty and extreme weather; it is difficult to live there otherwise. It is a rugged physical environment with an inherently variable climate. Summers are short and mild, while winters are long, cold and snowy. Lifelong residents of the EOH have adapted through a combination of household resilience and strong social networks within local communities and between neighbours. Household resilience is reflected in very high levels of self-sufficiency. Most hunt and fish, 
not simply for sport, but to supplement household food supplies. In addition to automobiles, most households have snowmobiles and/or ATVs, so they are never made completely housebound by winter storms. Virtually all homes have a wood stove so that the house can be heated, even if electricity is disrupted, which it often is, by fallen trees, high winds, or winter storms. Since household water is pumped from wells using electric pumps, households typically have a back-up generator. Because of the need to be self-sufficient, most adults are accustomed to hard physical labour and are at ease operating and repairing mechanical equipment. Households have historically been so independent, extreme weather events that produce states of emergency in more urbanized parts of Ontario are considered unremarkable in the $\mathrm{EOH}$.

As a simple example of self-sufficiency in action, when a fallen tree blocks a roadway in urban Ontario, a call is typically made to a municipal authority to dispatch workers to remove it. Such resources do not exist in the EOH. There, when a tree falls across a road - which happens rather often - the first person to arrive on the scene clears the tree away with a chainsaw or towing chains, things many residents keep in their vehicles for just such a purpose.

Very strong social networks within EOH communities complement household selfsufficiency. If someone is elderly or unwell and lacks adequate family support, neighbours and local church groups can be counted upon to keep watch and step in when needed. Local businesses will extend informal credit to families in times when household income is low. Community social bonds are reinforced on an on-going basis by regular participation in activities like hunting, fishing, church attendance, service club meetings, and spontaneously organized community poker games or snowmobile outings. Such events take place predominantly in the winter, which seasonal residents do not attend, meaning they do not share in the social capital of the community.

\section{Threats to adaptive capacity}

Adaptive capacity in the $\mathrm{EOH}$ is being undermined by three concurrent threats: changing climatic conditions, demographic change, and, macro-economic forces operating beyond the region. Each is now discussed in turn. 
Climatic conditions in the EOH have been changing observably over recent decades (McLeman, 2008). While still harsh by southern Ontario standards, winters in the EOH are becoming shorter, milder, and less snowy. To outsiders this may appear to be a favourable trend, but it has several negative impacts. First, it shortens the winter forestry season, since heavy equipment can only enter the forest when the ground is frozen solid. Because smallscale forestry is an important livelihood for many households, a shortened winter season reduces their incomes at a time of the year when other employment is scarce. Second, snowmobile trails in the EOH traverse lakes, rivers and wetlands. Milder winters make these unsafe. Snowmobiling is an important social activity for residents and attracts winter tourists from the south. Third, the single greatest expense for local governments is road maintenance, and milder winters increase this. Large volumes of sand and salt must be applied to de-ice road surfaces, and the repeated freeze-thaw cycles of mild winters cause road materials and culverts to break down faster and hasten the need for repairs.

For some workers and their families, the shorter winter could open up additional employment opportunities in the late autumn and early spring. For example, real estate agents report they are increasingly able to show recreational properties to potential buyers later into the year, since many of these properties can only be reached by boat or by roads that are closed once the snow flies. Correspondingly, local contractors can undertake renovation work on seasonal properties later into the autumn and earlier in the spring. Given the nature of the landscape and the distance of EOH communities from the rest of Ontario, it is unlikely that any new employment opportunities will emerge in the short term from milder springs and autumns.

Summers are becoming longer, and temperatures are generally milder. For a region where outdoor summer recreation is a key economic sector, this is generally positive, since visitors are more likely to stay longer and come more often when weather is mild. However, the summer tourist season is dictated mainly by school calendar, so milder weather in May and September has little tangible economic benefit. Meanwhile, hotter, dryer summer weather increases the risk of forest fires, and extreme wind events appear to be occurring more frequently than in the past. High winds damage properties and power lines with fallen trees, and make for hazardous boating conditions. Overall, the benefits of milder summer weather likely exceed the negative impacts, but for year-round residents the net negative impacts of milder winters outweigh any net summer benefits. 
A second challenge is the general aging of the population and the on-going out-migration of young people. Household resilience is predicated on members' physical strength and general health, and these invariably weaken with age. The average age of the population being now well over fifty, the majority of households are rapidly becoming less self-sufficient. The steady outflow of young residents means that the social networks that historically buttressed less-resilient households are not being replenished, but are eroding. The retirees who migrate into the community keep population numbers relatively stable, but they do not integrate well into community social networks. They have a different cultural background and have different lifestyle preferences from lifelong residents. They tend to create their own social networks, and are often least socially active during winter, assuming they have not left altogether for more southerly climes. Having lived in milder climates and less isolated settings, retirees also tend to be less self-sufficient than lifelong residents.

A key challenge for the community going forward is to find ways to bridge these two relatively separate sets of social networks and the social capital contained within each. There have been a few examples in recent years that show how this is possible. One is a local service club (the Lions Club) that is able to draw members from long-term residents and from recent retirees, and which dedicates itself to community improvements, such as the building of a skateboard park for youth. Another is a local economic promotion committee that has a broad mix of members, and which among other things has used climate change research generated by the projects described here to lobby the provincial government to extend the operating dates of the region's provincial park (a key attraction for tourists) later into the fall. While the emergence of such groups is promising, they draw in only a small number of residents. As such, it is questionable whether they can fully offset the decline in more traditional social networks or be able to fully bridge the relatively unconnected social networks of lifelong residents and newcomers.

A consequence is that the adaptive capacity of the population of the $\mathrm{EOH}$ in aggregate is steadily becoming more dependent on publicly provided services. These have never been especially available or well funded in the $\mathrm{EOH}$, and are increasingly being scaled down or withdrawn as higher levels of government wrestle with indebtedness that soared after the 2008 financial crisis. Where each community once had its own elementary school, a single school now serves the entire region, for students from kindergarten to the end of secondary school. Long school bus rides encourage young families to move elsewhere, and discourage 
new ones from settling in the region. Ambulance services are being reduced, even as the population ages and becomes more likely to need them. The provincial government has downloaded responsibility for aging physical infrastructure to local governments, meaning that the need to replace an essential bridge requires diversion of local funds that might otherwise be spent on social services.

These new demands on local governments and institutions take place within a context of broader macro-economic changes affecting the region, the province, and the country more generally. For example, in the 1990s the EOH was a popular destination for American tourists, but a rising Canadian dollar, increasing gasoline costs, and additional post-9/11 regulations placed by the US government on cross-border travel caused this source of visitors and corresponding tourist revenue to dry up. Rising fuel costs also cut into the budgets of local governments and households alike. As a result, residents and local governments in the EOH find themselves increasingly squeezed between a growing need for public spending, rising costs, and a shrinking set of potential revenue streams. The impacts of climatic variability and change add an additional layer of complexity to this dynamic.

\section{Case Study 3: Climate change impacts on migration in northern Norway}

This third case study considers the impacts of climate change on migration patterns in northern Norway and the consequent implications for the region's indigenous people, the Saami. The overall Saami population is estimated to be between 50,000-100,000 individuals with approximately 50-60\% living in Norway (Kelman \& Næss, 2013). As a traditional Saami practice, reindeer husbandry is legally recognised in Norway as a livelihood with 3,645 Saami officially recognised as being affiliated with reindeer herding, meaning the sum of license owners and those affiliated with the license owners (Anonymous, 2014). Reindeer husbandry has undergone major technological, economic, and political changes. Most notably, the production system has changed from being subsistence-based to a motorized and marketoriented industry (Næss and Bårdsen, 2013). Nevertheless, traditional knowledge of the best grazing areas in relation to changing environmental conditions is still pertinent to herding strategies (Solbakk, 2006). 


\section{Climate change and migration in northern Norway}

Climate change will bring sea-level rise to Norway, although in many places this may be somewhat offset because the land is rising relative to the sea due to on-going isostatic rebound since the last ice age. Norway's Arctic coast experiences frequent severe storms, but the impacts of climate change on Arctic storm parameters is unclear, especially due to interactions with changing sea ice. However, as a result of climate change, resource extraction-which for Norway is mainly offshore oil and gas-may become easier and cheaper. Meanwhile, storms notwithstanding, Arctic shipping routes seem likely to become increasingly ice-free in the summer and consequently be used more frequently (Wang \& Overland, 2009). Northern Norway is also becoming a more popular tourist destination, especially in the short-term as it becomes iconised as 'last chance' to see the Arctic before it melts (Hall \& Saarinen, 2010). These climate-driven changes create livelihood opportunities in resource extraction, shipping, tourism, and associated product and service sectors, adding to the already growing need for personnel in northern Norway.

Climate change will cause major changes to northern Norway's ecosystems, some of which will support reindeer herding and others that will make it more challenging. Despite this, climate change itself is expected to have limited impact on Norwegian Saami migration and is not likely to directly cause displacement (Kelman \& Næss, 2013). Instead, social and governance structures influence livelihoods in such a way that the Saami's connection to their environment is being undermined while adaptation options for maintaining their traditions are becoming more limited. This situation might cause Saami to move, either within northern Norway or towards the south. That is, the migration of Norway's indigenous people is not so much through abandoning traditional livelihoods because of climate change. Rather, climate change will lead to social changes in the community that, in turn, affect Saami choices of livelihoods and where to live. Further, the direct impact of the environmental factors on migration is likely to be modest in comparison to the policies, regulations, and governance structures influencing reindeer herding, most of which are not linked to climate change (Næss \& Bårdsen, 2013). A similar lack of any cause-effect relationship between climate change and migration holds for coastal Saami populations. Climate change is projected to increase fish stocks around coastal Norway while changing species composition and likely making more northern waters suitable for fish farming (Stenevik \& Sundby, 2007). Nonetheless, fishing is not a big influencer on coastal Saami livelihoods, meaning that the impacts on Saami migration will be small. 
Indigenous views are not homogenous, with many disagreements amongst the Norwegian Saami. However, the Saami are concerned that resource-related migration into northern Norway might be encouraged and supported without fully consulting with communities and without considering the full implications for lifestyles and livelihoods in the region. The Saami do not oppose resource extraction, shipping, tourism or in-migration per se, but they expect to be consulted about decisions, to have a say in order to protect their interests, and where decisions are to earn income, to share the proceeds.

\section{Overall consequences from and for migration}

Aside from the Saami, migration has always been a common feature of northern Norway. National policy (Government of Norway, 2009) has long supported people living throughout the country, including in the north, by providing financial incentives and supporting public services. As part of encouraging people to live in northern Norway, the Norwegian petroleum company Statoil set up an office in Harstad which employs 280-300 staff, many of whom are not originally from the region (Kelman \& Næss, 2013). Norway also settles many refugees and asylum seekers above the Arctic Circle under a dispersal policy that supports underpopulated regions and aims to avoid the ghettoization of refugees and asylum-seekers in larger centres. None of these policies leading to migration north are affected by climate change.

Despite these policies, the largely rural areas of northern Norway experience significant levels of outmigration. Youth often leave the region searching for education, larger settlements, or more varied livelihoods. Migration might initially be seen as temporary-for instance, for university or independent travel — but may become longer-term or permanent because the migrants prefer other locations or because their partners or families do not wish to live in the north. However there are many reasons for choosing to migrate-and for choosing the direction in which to migrate. Many cases exist of southerners marrying northern locals and then moving north — or simply choosing the northern lifestyle. For some Saami, education in the south and exposure to non-Arctic cultures can strengthen ties to land and traditions, convincing them to return north. The influence of climate change on migration is negligible compared to these social factors. 
Such social factors influence everyone, not just indigenous peoples. As another example, petroleum is particularly important for livelihoods in northern Norway and hence for migration and non-migration decisions. The first developed Norwegian oil and gas fields north of the Arctic Circle are near Hammerfest: the Snøhvit (Snow White) natural gas field which began production in 2007 and the Goliat oil and gas field for which development is undergoing planning. Hammerfest has been revitalised by this investment, drawing in many migrants from outside northern Norway to live there temporarily or permanently. People in Hammerfest and the nearby area generally see petroleum's impacts as being positive, providing economic revitalisation and strong social reasons for not migrating while bringing an influx of migrants for the available jobs. To a large extent, the people of Hammerfest expect and hope for continued in-migration as the proceeds from petroleum continue to flow, including with climate change making the resources more accessible.

\section{Discussion and conclusion}

The three case studies presented here highlight the variable nature of climate change impacts on sparsely populated regions in the mid-to-high latitudes. The climate of these regions has, in general, ensured that its residents are adaptable to extreme climate conditions and diverse natural hazards. However, the variable environmental, cultural, economic and social impacts of climate change could cause changes among these populations, especially keeping in mind that adaptation strategies themselves have social and cultural impacts (IPCC, 2012).

For example, the expansion of the residential area up on higher land offers an alternative to residents currently living in the low-lying region of Vík in southern Iceland other than migrating to another township. This is a positive, as it is a truism from decades of research that cultures are at risk when people are displaced from areas that they value. However, people with low economic capital, where their assets are tied to property that are vulnerable to climate change, face difficulties in moving away from impacts (Mendelsohn et al., 2006), such as sea level rise and coastal erosion.

With the current plans to relocate the national highway along the coast of Vík, the municipality is contradicting its own adaptation plans in the form of land use planning and protection strategies. Originally, land use plans did not consider the risk of coastal erosion in Vík but the present plan is greatly focused on structural mitigation to protect the built 
environment, in addition to, retreat strategies to a new permanent settlement on higher ground. The municipality's plan for a tunnel through Reynisfjall and relocation of the national highway onto the coast has been highly criticised by local residents because they believe it ignores the threat of coastal erosion, sea level rise, and expected tsunami following a Katla eruption, in addition to adverse damage to agricultural land.

When planning structural strategies, governments must take into account the financial costs, which are often great for construction, maintenance, and decommissioning/upgrading, as well as the fact that structural measures are only effective up to the limits of their design (Hallegatte, 2009). Furthermore, structural approaches can induce a false sense of security. For instance, the building of dams and reservoirs to reduce the risk of river floods and droughts as precipitation is altered under climate change can lead to the development of infrastructure in at-risk zones based on the assumption that the dam or reservoir will prevent disaster. In an instance where environmental events are beyond the structure's design limits, however, there are often far less preparedness and vulnerability reduction measures in place meaning far greater impacts than that which would have occurred if the structure had not existed. While risk may be reduced in the short-term it is increased in the long-term, in a phenomenon known as "risk transfer" from the present to the future due to the structural strategies (Etkin, 1999; Fordham, 1999; Tobin, 1995).

Meanwhile, changing climatic conditions have direct and observable implications for livelihoods and the wellbeing of residents. It creates additional costs and a small number of potential opportunities in a sparsely populated region such as the $\mathrm{EOH}$ that already struggles with chronic economic under-development and lack of physical and ICT infrastructure. However, the challenges presented by climate change have not emerged in isolation. The ability of communities like Vík and the EOH to adapt to climate change, and of Saami communities in northern Norway, will be determined by the interaction of climate with demographic change and wider macro-economic trends. Residents have no influence over macro-economic forces, but there is potential to influence positive outcomes of demographic change. One such method is via a migrant welcoming program, which is in place in Jokkmokk, the largest Saami village in Sweden. See http://www.focusjokkmokk.com/howwe-can-help/ for details. 
Because their populations are relatively small and have place-specific economic systems, sudden changes in demographic patterns/demographic characteristics of the population have significant implications for vulnerability and adaptive capacity. In the case of the $\mathrm{EOH}$, the outflow of young people, the inflow of older retirees and overall aging of population makes residents more dependent on institutions for adaptation, and less resilient at the community and household level. Vík also has an ageing population. However, given the longevity of residents, as opposed to an influx of retirees in the $\mathrm{EOH}$, there is still a certain level of community resilience based on connectedness, social capital and first-hand experience of environmental extremes, trends, and variability. In the long-term, however, if Iceland's policies and Strategic Regional Plan do not succeed in their goals of halting depopulation and these demographic changes continue in Vík, community resilience will diminish.

In each case study, traditional livelihoods are based on small-scale use of local resources (farming, fishing, forestry, herding). However, as outside economic forces like tourism, resource extraction (such as Norway's petroleum) and wealthy retirees (in the EOH) enter into the economy, strong community networks and social capital can be affected. Sometimes, they erode, inhibiting the ability of long-time residents to adapt to climate change. Sometimes, as seen in Hammerfest, they become much stronger and much more robust, giving the confidence and resources to deal with climate change — while recognizing that climate change seems likely to bring further economic opportunities to the city. It is also possible that the changes are neutral in terms of adaptive capacity, overall neither hindering nor helping, or being superseded by other factors such as immigration rather than emigration.

The integration of new residents into community social networks is essential to revitalizing community adaptive capacity in sparsely populated areas. Although potentially culturally different, new residents bring skills and education with similarities and differences to locals, often yielding significant benefits. This was seen in the EOH example, where recent arrivals joining local service groups led to the building of a skateboard park and greater lobbying of the government over park operating dates. It is unclear, however, whether these types of commitments to community social networks will be sufficient to maintain population stability and community viability.

Temporary and permanent migration in all forms - in-migration, out-migration, and circular migration - has long been a staple of communities in northern Norway. Climate change will 
impact migration patterns in northern Norwegian communities, but most likely through increasing rates of all forms of migration alongside more people settling in the communities. That includes migration into northern Norway from those seeking to pursue livelihood opportunities opened up by climate change leading to governance regimes permitting those opportunities to be pursued. Indigenous culture in northern Norway and indigenous migration patterns are likely to change, for good or bad with that judgement potentially being different with different perspectives, as a consequence. Even if the migrants are permanent, the undermining of indigenous culture might not support community stability and viability.

Topophilia theorised by Tuan (1974) describes place attachment which could cover any combination of reasons including culture, livelihoods, home, social cohesion, and identity. Although not detailed in the case studies described above, residents in the Icelandic and Norwegian communities studied demonstrate high levels of topophilia, with many in-migrants often adopting similar attitudes. Similarly, lifelong residents of the $\mathrm{EOH}$ have distinctive cultural and subsistence practices that hold for them considerable significance. Activities like fishing, hunting, trapping, and snowmobiling bring together extended families and communities, and provide opportunities to renew and strengthen social connections. To be from the EOH is to do, and enjoy doing, such activities - all feeding into topophilia. Some newcomers to the $\mathrm{EOH}$ (but not all) also embrace some of these activities, and in doing so embrace the identity of the region. Climate change is starting to impede residents' ability to participate in these activities, which erodes the social connectivity of the population, detrimentally affects topophilia as part of the changes to social cohesion and the activities, and provides youth — and often retirees — with yet another reason to consider lifestyle opportunities elsewhere. People with strong topophilia are likely to be unhappy when feeling forced to move from their home, which is one concern emerging from discussions of the potential for climate change related migration (IPCC, 2012). Our case studies provide additional reasons to conduct further research on this subject.

The actual and potential fluxes of migrants — in, out, and circular — paint a complex picture for settlement level impacts of climate change. Migration and settlement patterns and projections are never straightforward to predict or analyze given how many factors influence all such decisions. Climate change is one more aspect in all these factors - as are the societal responses to climate change, both mitigation and adaptation (and their connections and overlaps, since they are not truly separate activities), which for communities similar to those 
presented here might have more impact on people and their migration decisions than climate change.

In conclusion, the case studies canvassed in this chapter should be considered to be a sample of the larger challenges faced by northern communities as the impacts of climate change become increasingly manifest. The particular nature of the impacts will undoubtedly vary from one physical locale to the next, and the capacity of specific populations to adapt to those impacts will be strongly influenced by social, economic, and political forces unrelated to changes in the climate.

\section{Acknowledgements}

Research presented in this paper contributes to the Nordic Centre of Excellence for Resilience and Societal Security - NORDRESS, which is funded by the Nordic Societal Security Programme. Contribution is appreciated from Porsteinn Ari Porgeirsson for the development of Figures 1 and 2. Gríma Eik Káradóttir and Unnsteinn Gíslason from the Icelandic National Planning Agency are thanked for their efforts in searching and providing access to archived documents and maps. Ásgeir Ásgeirsson, the head of the municipality Mýrdalshreppur, is also thanked for providing valuable insights into the demography and culture of Vík.

\section{References}

ACIA, 2005. Arctic Climate Impacts Assessment. Cambridge University Press, Cambridge.

AMAP, 2011. Snow, Water, Ice and Permafrost in the Arctic. AMAP (Arctic Monitoring and Assessment Programme) Secretariat, Oslo.

Bird, D., Gísladóttir, G., 2012. Residents' attitudes and behaviour before and after the 2010 Eyjafjallajökull eruptions - a case study from southern Iceland. Bulletin of Volcanology 74, 1263-1279.

Bird, D., Gísladóttir, G., 2014. How the children coped with the April 2010 Eyjafjallajökull eruption in Iceland. Australian Journal of Emergency Management 29, 50-55.

Bird, D.K., Gísladóttir, G., Dominey-Howes, D., 2010. Volcanic risk and tourism in southern Iceland: Implications for hazard, risk and emergency response education and training. J. Volcanol. Geoth. Res. 189, 33-48.

Bird, D.K., 2010. Social dimensions of volcanic hazards, risk and emergency response procedures in southern Iceland, Department Geography and Tourism / Department of 
Environment and Geography. University of Iceland / Macquarie University, Reykjavik / Sydney, p. 235.

Bird, D.K., Gísladóttir, G., Dominey-Howes, D., 2011. Different communities, different perspectives: Issues affecting residents' response to a volcanic eruption in southern Iceland. Bull. Volcanol. 73, 1209-1227.

Björnsson, H., 2002. Subglacial lakes and jökulhlaups in Iceland. Global Planet. Change 35, 255-271.

Björnsson, H., Pálsson, F., 2008. Icelandic glaciers. Jökull 58, 365-386.

Carlsen, H.K., Hauksdottir, A., Valdimarsdottir, U.A., Gíslason, T., Einarsdottir, G., Runolfsson, H., Briem, H., Finnbjornsdottir, R.G., Gudmundsson, S., Kolbeinsson, T.B., Thorsteinsson, T., Pétursdóttir, G., 2012a. Health effects following the Eyjafjallajökull volcanic eruption: a cohort study. BMJ Open 2.

Carlsen, H.K., Gislason, T., Benediktsdottir, B., Kolbeinsson, T.B., Hauksdottir, A., Thorsteinsson, T., Briem, H., 2012b. A survey of early health effects of the Eyjafjallajökull 2010 eruption in Iceland: a population-based study. BMJ Open 2.

Compton, K., Bennett, R.A., Hreinsdóttir, S., 2015. Climate-driven vertical acceleration of Icelandic crust measured by continuous GPS geodesy. Geophys. Res. Lett. 42, 2014 GL062446.

Engen-Skaugen, T., Benestad, R., Førland, E.J., 2008. Results from ESD analyses on precipitation representing twenty-five Norwegian catchments. Report 23. Norwegian Meteorological Institute, Oslo.

Etkin, D., 1999. Risk transference and related trends: driving forces towards more megadisasters. Global Environmental Change Part B: Environmental Hazards 1, 69-75.

Flannigan, M.D., Bergeron, Y., Engelmark, O., Wotton, B.M., 1998. Future Wildfire in Circumboreal Forests in Relation to Global Warming. J. Veg. Sci. 9, 469-476.

Fordham, M., 1999. Participatory planning for flood mitigation: models and approaches. Australian Journal of Emergency Management 13, 27-34.

Galeczka, I., Oelkers, E.H., Gislason, S.R., 2014. The chemistry and element fluxes of the July 2011 Múlakvísl and Kaldakvísl glacial floods, Iceland. J. Volcanol. Geotherm. Res. 273, 41-57.

Government of Norway, 2009. St.meld. nr. 25: Lokal vekstkraft og framtidstru. Om distriktsog regionalpolitikken. Government of Norway, Oslo.

Guðmundsson, M.T., Gylfason, Á.G., 2005. Hættumat vegna eldgosa og hlaupa frá vestanverðum Mýrdalsjökli og Eyjafjallajökli. Ríkislögreglustjórinn and Háskólaútgáfan, Reykjavík.

Guðmundsson, M.T., Larsen, G., Höskuldsson, Á., Gylfason, Á.G., 2008. Volcanic hazards in Iceland. Jökull 58, 251-268. 
Hall, C.M., Saarinen, J., 2010. Last Chance to See? Future Issues for Polar Tourism and Change, In: Hall, C.M., Saarinen, J. (Eds.), Tourism and Change in Polar Regions: Climate, Environments and Regions. Routledge, London, pp. 301-310.

Hallegatte, S., 2009. Strategies to adapt to an uncertain climate change. Global Environmental Change 19, 240-247.

Hannesson, P., 1950. Letter written by Pálmi Hannesson on behalf of the Icelandic Research Agency to the Icelandic Planning Office.

Hanssen-Bauer, I., 2009. Klima i Norge 2100. Bakgrunnsmateriale til NOU Klimatilpasning. Norsk klimasenter - Departementenes servicesenter, Oslo.

Haraldsson, J.T., 1982. Vík í Mýrdal. Myndun porpsins og próun. Dynskógar 1.

Icelandic Tourist Board, 2015. Foreign visitors to Iceland 1949-2014, http://www.ferdamalastofa.is/en/recearch-and-statistics/numbers-of-foreign-visitors, Accessed: 26 July 2015.

IPCC, 2013. IPCC Working Group I Fifth Assessment Report. Intergovernmental Panel on Climate Change, Geneva.

IPCC, 2012. Managing the Risks of Extreme Events and Disasters to Advance Climate Change Adaptation. A Special Report of Working Groups I and II of the Intergovernmental Panel on Climate Change. Cambridge University Press, Cambridge, UK.

Ísaksson, G., Viggósson, G., Jóhannesson, H., Pálsson, S., 2005. The beach in front of Vík. Second International Coastal Symposium, Höfn, Iceland, p. 8.

Jóhannesdóttir, G., Gísladóttir, G., 2010. People living under threat of volcanic hazard in southern Iceland: vulnerability and risk perception. Nat. Hazards Earth Syst. Sci. 10, 407-420.

Jóhannesdóttir, G., 2005. Við tölum aldrei um Kötlu hér mat íbúa á hættu vegna Kötlugoss, Department of Geology and Geography. University of Iceland, Reykjavík, p. 103.

Jónsdóttir, Á., 2012. Experiencing environmental changes in Vík, southern Iceland. CoastAdapt, Reykjavík, p. 41.

Kelman, I., Næss, M.W., 2013. Climate Change and Displacement for Indigenous Communities in Arctic Scandinavia. Center for International Climate and Environmental Research, Oslo, p. 26.

Larsen, G., 2000. Holocene eruptions within the Katla volcanic system, south Iceland: Characteristics and environmental impact. Jökull 49, 1-28.

Loftsson, M., 1930. RIT um Jarðelda á Íslandi. Skúli Markússon, Reykjavík.

Lögreglustjórinn á Hvolsvelli, Almannavarnanefnd Rangárvalla- og V-Skaftafellssýslu, Ríkislögreglustjórinn, 2013. Viðbragðsáætlun vegna eldgoss undir Mýrdalsjökli.

Maclennan, J., Jull, M., McKenzie, D., Slater, L., Grönvold, K., 2002. The link between volcanism and deglaciation in Iceland. Geochemistry, Geophysics, Geosystems 3, 1062. 
McLeman, R., 2008. Economic and Social Adaptation to Climate Change in Canadian Seasonal-economy Communities: Final Scientific Report. Natural Resources Canada, Ottawa.

McLeman, R., Gilbert, G., 2008. Adapting to climate change in Addington Highlands: A report to the community. University of Ottawa, Ottawa.

McLeman, R., 2010. Impacts of population change on vulnerability and the capacity to adapt to climate change and variability: a typology based on lessons from "a hard country". Population and Environment 31, 286-316.

McLeman, R., Foy, N., Clark, K., 2010. Adaptive capacity-building and sustainable development in Canadian rural and remote communities: The role of information and communication technologies. Social Science and Humanities Research Council Knowledge Synthesis Report, Ottawa, p. 42.

McLeman, R., 2009. Climate change and adaptive human migration: lessons from rural North America, In: Adger, N.W., Lorenzoni, I., O'Brien, K. (Eds.), Adapting to climate change: thresholds, values, governance. Cambridge University Press, Cambridge, pp. 296-310.

McLeman, R., Ford, J.D., 2013. How Demographic Change and Migration Influence Community-Level Adaptation to Climate Change: Examples from Rural Eastern Ontario and Nunavut, Canada, In: Faist, T., Schade, J. (Eds.), Disentangling Migration and Climate Change: Methodologies, Political Discourses, and Human Rights. Springer, Berlin, pp. 55-79.

Mendelsohn, R., Dinar, A., Williams, L., 2006. The distributional impact of climate change on rich and poor countries. Environment and Development Economics 11, 159-178.

Mýrdalshreppur, 1977. Aðalskipulag Víkur í Mýrdal, Mýrdalshreppi 1975-1995. Approved August 11, 1977.

Mýrdalshreppur, 2010. Aðalskipulag Mýrdalshrepps, 2009-2025. Approved: December 22, 2010.

Mýrdalshreppur, 2013a. Tillaga að breytingu á aðalskipulagi (Aðalskipulag Mýrdalshrepps 2012-2028). Approved: June 12, 2013.

Mýrdalshreppur, 2013b. Aðalskipulag Mýrdalshrepps, 2012-2028. Approved: March 5, 2013.

Óladóttir, O.P., 2015. Tourism in Iceland in figures. Ferðamálastofa, Reykjavík, p. 27.

Ólafsson, K., 1987. Verslunarsaga Vestur -Skaftfellinga. Hundrað ára verslun í Vík í Mýrdal. Fyrra bindi, Vík, Vestur Skaftafellssýsla.

Ólafsson, K., 1991. Verslunarsaga Vestur-Skaftfellinga. Hundrað ára verslun í Vík í Mýrdal. Annað bindi, Vík, Vestur Skaftafellssýsla.

Ólafsson, K., 1993. Verslunarsaga Vestur -Skaftfellinga. Hundrað ára verslun í Vík í Mýrdal. priðja bindi, Vík, Vestur Skaftafellssýsla.

Pagli, C., Sigmundsson, F., 2008. Will present day glacier retreat increase volcanic activity? Stress induced by recent glacier retreat and its effect on magmatism at the Vatnajökull ice cap, Iceland. Geophys. Res. Lett. 35, L09304. 
Parliament of Iceland, 2014. Parliamentary Resolution on a Strategic Regional Plan for the years 2014-2017, http://www.byggdastofnun.is/static/files/Byggdaaaetlun1417/parliamentary-resolution-on-astrategic-regional-plan-for-the-years-2014-2017.pdf, Accessed: 30 June 2015.

Prime Minister's Office, 2011. Iceland 2020 - governmental policy statement for the economy and community, http://eng.forsaetisraduneyti.is/iceland2020/, Accessed: 30 June 2015.

Rose, W.I., Durant, A.J., 2009. Fine ash content of explosive eruptions. J. Volcanol. Geotherm. Res. 186, 32-39.

Sambaraju, K.R., Carroll, A.L., Zhu, J., Stahl, K., Moore, R.D., Aukema, B.H., 2012. Climate change could alter the distribution of mountain pine beetle outbreaks in western Canada Ecography 35, 211-223.

Scheffer, M., Hirota, M., Holmgren, M., Van Nes, E.H., Chapin, F.S., 2012. Thresholds for boreal biome transitions. Proceedings of the National Academy of Sciences 109, 2138421389.

Sigvaldason, G., Annertz, K., Nilsson, M., 1992. Effect of glacier loading/deloading on volcanism: postglacial volcanic production rate of the Dyngjufjöll area, central Iceland. Bulletin of Volcanology 54, 385-392.

Statistics Iceland, 2013. Population by municipalities, sex and age 1 January 2014 Mýrdalshreppur, http://statice.is/Statistics/Population/Municipalities, Accessed: 13 January 2015.

Statistics Iceland, 2014a. Population by urban nuclei, age and sex 1 January 2014 - Vík í Mýrdal, http://statice.is/Statistics/Population/Urban-nuclei-and-zip-codes, Accessed: 13 January 2015.

Statistics Iceland, 2014b. Tourism, transport and IT: Tourist accommodation 2013, http://www.statice.is/lisalib/getfile.aspx?ItemID=16563, Accessed: 13 January 2015.

Statistics Iceland, 2015. Statistics » Wages, income and labour market » Labour market, http://www.statice.is/Statistics/Wages,-income-and-labour-market/Labour-market, Accessed: 26 July 2015.

Stralberg, D., Matsuoka, S.M., Hamann, A., Bayne, E.M., Sólymos, P., Schmiegelow, F.K.A., Wang, X., Cumming, S.G., Song, S.J., 2015. Projecting boreal bird responses to climate change: the signal exceeds the noise. Ecol. Appl. 25, 52-69.

Sveinsson, Ó.J., 1988. Guðað á glugga. Dynskógar 4, 221-224.

Sverrisson, E.E., 1988. Víkurkauptún 1890-1930. Dynskógar 4.

Tobin, G.A., 1995. The Levee Love Affair: A Stormy Relationship? Journal of the American Water Resources Association 31, 359-367.

Tuan, Y.-F., 1974. Topophilia: A Study of Environmental Perception, Attitudes, and Values. Columbia University Press, New York. 
Tuffen, H., 2010. How will melting of ice affect volcanic hazards in the twenty-first century? Philosophical Transactions A 368, 2535-2558.

Veðurstofa Íslands, 2013. Loftslagsbreytingar og áhrif peirra - staðan 2013. Samantekt skýrslu vinnuhóps 1, WGI, hjá Milliríkjanefnd Sameinuðu pjóðanna IPCC,

http:/www.vedur.is/loftslag/rannsoknir/ipcc/ipcc-2013/, Accessed: 20 November 2014.

Veðurstofa Íslands, 2014. Ársmeðaltöl fyrir stöð 798 - Vík í Mýrdal, http://www.vedur.is/Medaltalstoflur-txt/Stod_798_Vik_i_Myrdal.ArsMedal.txt, Accessed: 20 November 2014.

Vegagerðin, 2008. Hringvegur (1-b2/b4) um Mýrdal. Frumdrög. Veghönnunardeild, Vegagerðin.

Verkfræðistofan Vatnaskil, 2014. Múlakvísl. Hermun flóða við fyrirhuguð brúarmannvirki og varnargarða og mat á áhrifum hamfaraflóðs á Kötlugarð. Skýrsla nr.14.03.

Wang, M., Overland, J.E., 2009. A sea ice free summer Arctic within 30 years? Geophys. Res. Lett. 36, L07502.

Pingskjal 855 - 495. mál, 2014. Tillaga til pingsályktunar um fjögurra ára samgönguáætlun fyrir árin 2013-2016, https://http://www.althingi.is/altext/143/s/pdf/0855.pdf, Accessed: 13 January 2015. 